\author{
Serhii Hlibko \\ Scientific and Research Institute of Providing Legal Framework for the Innovative Development of National \\ Academy of Law Sciences of Ukraine, Kharkiv \\ 61002, Kharkiv, Chernyshevskaya st., 80, Ukraine, ndipzir@gmail.com \\ https://orcid.org/0000-0003-3398-9276
}

\title{
LEGAL ISSUES OF THE FORMATION AND FUNCTIONING OF THE NATIONAL INNOVATION SYSTEM IN UKRAINE
}

\begin{abstract}
Introduction - the purpose of the article is to determine the theoretical and legislative bases for the definition and construction of the national innovation system and its subsystems, to establish gaps in the regulatory legal regulation of the economic activity of individual elements - subjects of the NIS.

Methods of research - structural and functional methods of analysis are used to determine the existing competence of the participants of the national innovation system of Ukraine and the ability to perform the necessary functions for the system. Methods of analysis and synthesis were used in the study of theoretical models of innovative systems and their structure. The normativist method (formal and legal) was used in the study of the actual state of legislative securing of the NIS.

Results of the research - Based on the analyzed scientific sources and on the basis of regulatory acts of Ukraine, it is necessary to distinguish the following NIS subsystems, which require significant legislative regulation: subsystem of generation of knowledge and education, subsystem of production of products and services, subsystem of innovative infrastructure, subsystem «National network technology transfer», Territorial (regional) subsystems.

Discussion with the other scientists - most views on the essence of a NIS can be divided into the following groups: structural approach, subsystem approach, functional and structural. However, these models do not sufficiently address the role of the lowest level of the administrative system - the united territorial communities as the only one as close as possible to the governmental structure. In this direction, it is necessary to extend the limits of financial capacity of territorial communities on the principles of transparency, accessibility, sufficiency.

Summary and conclusions - for the harmonious and timely development of the National Innovation System it is necessary to comprehensively approach the legislative regulation of relations in the innovation system and its subsystems, as well as to formulate guidelines for the formation of the system of regulation of innovative activity in the laws.
\end{abstract}

\section{Keywords}

National innovation system, NIS subsystems, technology transfer system, regional NIS subsystems, innovation code.

\section{Nomenclature, Abbreviations}

NIS - national innovation system.

CMU - Cabinet of Ministers of Ukraine

\section{Introduction}

The building up of the innovation system is a key task and a strategic state priority for present-day Ukraine. It is the transition to innovative development on the basis of the economy's innovative platform that will enable Ukraine to pass from an economy of consumption to that of development. By way of solving this complicated problem, our state will have to achieve a number of goals which will stipulate the creation of necessary preconditions for building up an economy of an innovative type. These goals are:

- ensuring stable economic growth

- approving an innovative state development model

- social redirection of economic policies.

As the lower-order tasks, one should consider the implementation of such measures pointed out by scientists as the formation of a normative-legal base and economic mechanism for sustaining and stimulation of innovative activities; determining and support of priority directions in innovative activities; outlining and implementation of state, branch, regional, and local innovation programs; protection of rights and interests of innovative activities subjects; financial support of innovative projects' implementation; stimulation of commercial banks and other finance-crediting institutions that provide credits for accomplishing innovative projects; establishing 
favorable taxation for innovative activities subjects; support for the development and functioning of modern innovative infrastructure.[1].

There were also different attempts made by scientists to illustrate the elements and connections that make up the innovations system, as well as the flows of information and resources within the system, and between the system and its environment. Thus, an analytic distinction between the "narrow" concept of NIS, which includes institutions and policies immediately involved in scientific and technological innovations, and the broad understanding of NIS, which takes into account the social, cultural and political environment, as well as the studied country was made. The narrow version is "an integrated system of economic and institutional agents that immediately enhance appearance the and application of innovations in the national economy", depending on one or several strategies discussed above. [2] Despite the fact that there are great differences between national economies and tremendous complexity within the system, it is possible to determine the characteristics of the key innovations subjects.

The OECD's specific approach to solving this theoretic issue, which in its documents and manuals applies doctrinal interpretations by leading scientists without giving preference to any of them, is noteworthy. In particular, as written in one of its documents, Freeman considers the NIS as a network of institutions in the public and private sectors, which in the course of their activities and interaction initiate, import, modify, and spread new technologies. Lundvall sees it as elements and relationships that interact in production, spreading, and the application of new economically useful knowledge... and are located or stay within the borders of a nation state. Nelson views it as a set of institutions, whose interaction determines innovative activities ... of national companies. Patel and Pavitt define it as technological training (or an amount and content of activities that generate changes) in a country. Metcalf treats it as a set of various institutions that jointly and individually promote the development and spreading of new technologies and which sets the limits wherein governments form and implement their policies to influence innovation process. Thus, it's a system of mutually connected institutions for generating, storing, and passing the knowledge, skills, and artefacts that determine new technologies.[3]

\section{Method of research}

Structural and functional methods of analysis are applied to determine the existing competence of the participants of the national innovation system of Ukraine and the ability to perform the necessary functions for the system.

The national innovation system is not considered in the broad sense, but only one that consists of specialized actors, both private and public, also with the participation of authorized bodies.

Methods of analysis and synthesis were used in the study of theoretical models of innovative systems and their structure. Attention was paid to the institutional construction of innovative systems and the functional, according to the directions of economic competence of NIS participants or the economic and administrative competence of participants - authorized bodies.

The further application of the results of theoretical analysis has led to the need to compare theoretical models of NIS construction and operation with the actual state of the normative regulation of innovation relations.

The normativist method (formal and legal) was used in the study of the actual state of legislative consolidation of the concept, the structure of the national innovation system and the economic and legal competence of its participants.

\section{Results of the research}

Solving these tasks is inseparably based on understanding the concept of the national innovation systems (hereinafter the NIS). Here, the notion of "national" is to be interpreted as the "state" innovation system, while in some sources, the NIS is opposed to the globalized innovation system, although it is acknowledged as a necessary phenomenon for economic development in each country.

In her reviewing of the understanding of national innovation systems, G.P. Klimova notes the variety of innovation systems and, summarizing the existing in scientific literature points of view, points out that innovation systems that exist on macro-, meso-, micro-, and local levels should be singled out. On the macrolevel, it is the world innovation system, international and transnational systems that constitute it, including the NIS. Regional innovation systems can be distinguished on the meso-level, branch (cluster) innovation systems on the micro-level, and innovation system of a specific enterprise on the local level. [4]

The national innovation systems of separate countries are considerably different form one another, which is manifested in the choice of priorities and tasks of innovative development, the mechanisms of interaction between the state and the private sectors, the significance of big and small business, the proportion between fundamental and applied research and development, the dynamics in development and branch structure 
of innovative activities. According to this, several basic models of national innovation systems are distinguished in the world practice: the Euro-American, Japanese, South-east-Asian, and the alternative innovation systems. [4]

In A. A. Kayal's opinion, a NIS is composed of a totality of mutually connected elements, components, links, and attributes. Components, as the scientist sees them, are operational parts of the system and exist in the forms of both separate persons and organizations like: business companies, banks, universities, science-research institutes, and state power bodies. Apart from, A.A. Kayal relates to the components of the NIS structure in higher education institutions, techno-parks and techno-polices, as well as technologies transfer centers. [5]

Analyzing the structural elements of a big (in a broad sense) NIS, determined by W.F. Maloney, it is possible to conclude that the scientist relates to the NIS components in universities, analytical centers, technologies dissemination centers, as well as the government and the market. [6]

S. Feinson notes that the acquisition and implementation of technological possibilities presupposes heavy investments in technological and social infrastructure. For countries with limited resources that can be directed to the NIS development and operation, Ch. Edquist has presented the concept titled Systems of Innovations for Development (SID). The SID highlights some key differences from the NIS approach in developed economies. He claims that four main spheres in which SID differs from NIS exist:

- the innovation product is more important than innovation processes through influencing the product structure;

- gradual innovations are more important and attainable than radical ones;

- innovations' broadening is more important than the development of new innovations in the world;

- innovations in the branches with low and medium technologies are more attainable than those in hightechnological systems. [7]

- In any event, developing countries can (through getting an assistance in educating or through agreements to avoid paying foreign companies) facilitate the national potential through various components of NIS necessary for long-term industrial and economic development. [8]

- S. Feinson, when analyzing the OESR documents, divided the NIS institutions into five categories:

- governments (local, regional, national, and international with different weight in different countries) that play the key role in determining the broad directions in policies;

- intermediary institutions like scientific councils and research associations that pose as mediators between governments and researchers;

- $\quad$ private enterprises and research institutes financed by governments;

- flows of knowledge, innovations, and education in the developing countries;

- universities and affiliated institutions that provide key knowledge and skills;

- $\quad$ other state and private organizations, which play a certain role in the national innovation systems (state laboratories, technology transfer organizations, joint science-research institutes, patent offices, training organizations, etc.). [7]

At the all-European level, one of the most wide-spread definitions of this legal category is the one supposed by Bengt-Ake Lundvall, who views it as a system of organizations and institutions, taking part in research, like R\&D departments, technological institutes and universities. [9]

In Ukraine, a legally set NIS structure is nonexistent, which leads to the problem of the definition of the very notion of NIS, so there is currently no unified determination of the notion of a NIS neither in the national, nor in the international legislation.

Applying structural and functional methods it is possible to state that unlike the national normative approach, the European theoretical base stems from the two main understandings of the NIS: 1) as a system of institutions that create, realize, and apply innovations, or enhance such activities; 2) as a system of relationships, in the course of whose implementation the creation, execution, and application of innovations takes place.

Contrary to this, despite the use of activity terminology, the national legal system considers the NIS as wide network of state and non-public institutions that perform specific functions facilitating innovations development through a system of all-sided legal, material-economic, education, production, and other relations between each other.

Departing from what was previously stated, it is possible to conclude that the national approach to the understanding of the essence and the contents of the NIS, on the whole, corresponds to the international one. The advantage of the normative fixating in the legislation of Ukraine is a structured enumeration of the NIS components by the functional principle. Among the main functions of such components, the following functions can be singled out: the normative and the control functions, qualification improvement function, informationcommunicative, material-technical, production, and other functions. Thus, each of the NIS elements is involved 
at a specific stage of the innovative process from the stage of the arising of an idea to the production and implementation of innovative goods, forming the necessary conditions for innovation development in Ukraine. Ukraine's programming documents contain an extensive NIS structure. According to the Concept of development of the national innovation system, the NIS is a set of legislative, structural and functional components (institutions) involved in the process of creation and the application of scientific knowledge and technologies and defining the legal, economic, organizational and social conditions for ensuring the innovation process. According to this NIS regulatory act, it consists of an extensive network of subsystems, such as the subsystem of state regulation, education, knowledge generation, innovative infrastructure and production. [10]

\section{NIS subsystems}

To build a legal mechanism for regulating a NIS state, it is necessary to isolate its subsystems using the methods of analysis and synthesis of the elements and functions of these subsystems. A. A. Kayal subdivides the NIS into the following main subsystems:

- $\quad$ science and technical policies

- innovation strategy

- human support technical service

- technical support services

- $\quad$ mobilizing of financial resources

- international cooperation. [5]

The review documents recognized the NIS subsystems as follows: state regulation, knowledge generation, innovative infrastructure; production. [11] Some scientific and review sources also refer to the sectoral formation of NIS subsystems. We believe that this option requires more detailed research regarding the discussion of the practical application of the components of one logical system that are different in function.

On the grounds of scientific sources previously analyzed, and on the basis of normative-legal acts of Ukraine, we will distinguish the following NIS subsystems, which we will view in the following enumeration.

\section{Knowledge generation and education subsystems}

The knowledge generation subsystem is understood as a total sum of organizations that are engaged in fundamental research and development, as well as in applied research.

In this aspect, L.I. Fedulova notes that education, as one of the key subsystems of a NIS, becomes the nucleus of he innovative development territory. It is connected, among others, with creating numerous innovative structures on the basis of higher education institutions (HEI). This is to say, that the understanding of the role of higher education within the innovation process becomes broader: on the higher education basis not only science-research and research-and-design projects are created, but also other wholesome structures are formed, which enable an efficient innovation process to be performed. [12]

E. Viotti asserts that in the case of economic development "training can be determined as a process of technical changes achieved through diffusion (from the perspective of technologies assimilation) and gradual innovations. In other words, training is the consumption of existing methodologies, that is, the consumption of innovations developed elsewhere and generating improvements for obtained methodologies". [13] For developing countries, as S. Feinson explains, it should be taken into account that training takes place on three analytical levels: 1 ) the main functions of a system; 2) broad strategies that can be used for efficient the creation and management of these functions; 3) subjects, institutions, and links within the system that mutually realize this strategy.[8] As S. Feinson observes, the countries with weak higher education systems lack quality human capital to train, for which a strong primary and secondary education is needed.[8]

It is correctly noted that in national innovation system of all countries generating innovations is made by industrial science, state research institutes, as well as research universities. As a specific form of scientific and education activity organization, a research university is intended to considerably intensify innovative activities in higher education. A distinctive sign of such a university is the ability to generate new scientific knowledge on the basis of a wide range of fundamental and applied research, the possibility of transferring technologies to the real sector of the economy and the availability of an efficient system of highly qualified personnel training. These characteristics determine a university's innovative road of development, which is connected with the introduction of new technologies, ideas, and knowledge to the scientific-and-research process with the aim of their practical application. [14]

It is also necessary to agree that a mandatory attribute of universities' innovation process should be the innovation climate, and a condition of its formation is a clear presence of three components in a university's activity: education, science, and novelties generation. [15] 


\section{Production of goods and services subsystem}

The subsystem of goods and services production includes, first and foremost, science-containing goods which are maintained by both large corporations and small and medium enterprises operating in the sphere of sciencecontaining business.

It is correctly noted in previous research that a peculiarity of Ukrainian legislation is indirect regulation of highly technological produce export support. As components of highly technological branch development, the presence of management mode, education development, innovations development and that of the engineering-designand-technology infrastructure have been determined, meaning that the industrial aspect starts with the development of separate NIS subsystems. [16]

It seems that in the course of the improvement of legal regulation of innovative activities in Ukraine, the experience of industrially developed countries should be considered, namely the practices of innovation activity support, like preferential taxation for enterprises that develop innovative products; granting zero-interest credits, compensations, donations, etc., partial or complete financing of innovative goods production. All the mentioned supporting measures indicate that legal regulation of innovative activities and innovation legal relations' development have to be built-up on the principle of creating and ensuring favorable conditions for innovative entrepreneurship. [17]

\section{Innovation infrastructure subsystem}

The Law "On Innovation Activity" [18] doesn't clearly specify the enumeration of the innovative infrastructure participants, but only provides the list of their functions. Contrary to that, a non-specific regulation in relation to innovative activities - Lawof Ukraine "On Development and State Support of Small and Medium Entrepreneurship (SME) in Ukraine" relates to the objects (or rather subjects) of SME support infrastructure business centers, business incubators, innovation business incubators, science-technology centers, technologies transfer centers, small entrepreneurship support funds, leasing companies, consultative centers, other enterprises, offices, and organizations. [19]

According to its functional aims, the innovative infrastructure contains the following elements: businessinnovational, telecommunication networks and retail chains, techno-parks, business incubators, innovationtechnological centers, consulting companies, financial structures, etc. It is possible to agree that the main purpose of innovation infrastructure is support, assistance, as well as resource and financial provision of the innovation process (finance-credit, material-and-technical, information, personnel support). [20]

To sum up, it is possible to note that innovative infrastructure institutions formation takes place under the influence of three groups of factors: legislative; organizational-managerial; economic ones. These factors should also account for the existing of the components of the "information infrastructure" subsystem: technologies, commodities, and services.

\section{"The national network of technologies transfer" subsystem}

The inter-regional technologies transfer network was established by the Ministry of Education and Science of Ukraine on the basis of the Ukrainian Institute of Science-Technical Expertise and Information (UkrINTEI) in the course of the "Inter-Regional Technologies Transfer Network Development" project realization.

V. Gurova singles out the main NIS determinants that, in our opinion, can be related to the functions of the subsystem of education and technologies transfer:

- $\quad$ establishing of research centers at the leading universities;

- development of links between higher education establishments and the corresponding branch of industry;

- development of cooperation on the basis of the network system between the national innovation system's elements on mutually profitable, coordinated, and parity conditions along with working out a common development strategy. [21]

\section{Territorial (regional) subsystems}

Access to innovation structures and participation in the national innovation system is possible with the proper ensuring of regional structures' activities and legal regulating the competencies of the NIS subjects on the regional level.

Intense attention to the issue of regions' innovative development attests to the importance of certain regional resources in the aspect of stimulating innovation possibilities and the competitiveness of corresponding economy subjects. In this connection, it is important to accentuate that the key goal in forming the regional innovation system is to enhance activation of the regional innovation activities and to increase a region's 
competitiveness level. At the current conditions of innovative processes intensification, the raise in attention to regions' innovation development becomes even more urgent and calls for permanent monitoring. Consequently, the efficient formation and development of regional innovation systems should take place in conditions of increasing competitiveness and corresponding stimulation of the regional innovative activities. [22]

\section{The information-communicative technologies subsystem}

As this subsystem's component, one should also consider the totality of information infrastructure, which is also related to the "innovation infrastructure" subsystem.

One of key factors of such a subsystem's functioning is the Digital Agenda for Europe adopted in 2010 and intended till 2020. Most of the EU countries considered it as the mainframe and adopted corresponding National Programs of Digital Society Development for $1-3$ years where they provisioned priority medium-term and shortterm goals and indicators of attaining those goals. A draft law was developed in Ukraine in 2017 "On Digital Agenda in Ukraine", but it was never adopted a law. The Concept of Digital Economy and Society Development of Ukraine for 2018 - 2020 approved by the Decree of the Cabinet of Ministers of Ukraine of January 17, 2018 No. 67-p, is currently in force.

At present, the Ministry of Digital Transformation of Ukraine coordinates state power bodies' activities regarding digital transformations in Ukraine, including those connected with the EU Program "Common

Digital Market". Thus, in accordance with the Regulation on the Ministry of Digital Transformation of Ukraine, adopted by the Cabinet of Ministers of Ukraine's Decree of September 18, 2019 No. 856, the mentioned Ministry ensures the formation and realization of state policies: in the spheres of digitalization, digitalized development, digital economy, digital innovations, electronic government and electronic democracy, information society development, informatics; in the sphere of citizens' digital skills development and digital rights; in the spheres of open data, development of national electronic information resources and interoperation, development of broadband access to the Internet and telecommunications infrastructure, electronic commerce and business; in the sphere of electronic and administrative services provision; in the spheres of electronic trust services and electronic identification; in the sphere of IT industry development. [23]

One of elements of the information-communicative technologies subsystem is Grid-technologies. Their popularity has just recently started growing, though their introduction began in Ukraine as early as in the mid2000s with the Decree of the National Academy of Sciences of Ukraine's Council of 25.04.2006 No. 249 "On Approving the Concept of the Program on Grid-Technology Introduction and Formation of Clusters". They were promoted thanks to the implementation of the of the State Science-Technical Program of Grid-Technologies introduction and application for the period of 2009-2013 and the Target Complex Program of Scientific Research by the National Academy of Sciences (NASc) of Ukraine "Grid-Infrastructure and Grid-Technologies for Science and Science-Applied Uses" approved by the Decree of the NASc of Ukraine Council of December 11, 2013 No. 164-a for 2014 - 2018.

Nevertheless, the recognition of the efficacy and convenience of Grid-technologies application takes place episodically and non-systematically. Lately, the notion of grid-technologies appears ever more often in the national legislation. Thus, in the new Law of Ukraine "On Scientific and Science-Technical Activities" a "grid" is defined as a part of research infrastructure. In the Supreme Council of Ukraine's Resolution "On the Parliament Hearings Recommendations on the Issue of 'On the State and Legislative Support of the Country's Science and Science-Technical Base" there is recognition of the functional advantage of Grid-technologies application. In particular, it is noted that "in the middle of 2012, Ukraine entered the top-ten European countries in terms of the number of internet users; about 15 million of Ukrainians have access to the world web. The national Gridinfrastructure has been created, which is integrated with the European one and is actively working on solving super-complicated tasks of modern physics, chemistry, and biology". [24]

Using the normativistic (formal-legal) method, the author conducted a separate analysis of the NIS, its structure and elements on two issues, in which normative legal acts determine the entity as a subject of law, its organizational and legal form and whether the economic competence of NIS participants is present. As a result, the following conclusions were obtained.

1. The concept and structure of the NIS are not contained in the laws, only in the by-laws: Concepts of development of the national innovation system and the Regulations on the procedure for the creation and operation of technoparks and innovative structures of other types. [25] The NIS subsystem - the technology transfer system is not regulated at all by regulations.

2. As members of NIS, among private legal entities, the concept and status of scientific [26], technological [27] and industrial [28] parks, as well as innovative enterprise [18] are enshrined in the laws.

3. Other innovative structures (business centers, business incubators, science and technology centers, technology transfer centers, small business support funds, leasing companies, innovation and advisory 
centers, technopolises, innovation clusters, venture funds) are only prescribed by law [19] [29] [30], without fixing their status as a legal entity or other entity.

4. The status of NIS participants in the National Council of Ukraine for the Development of Science and Technology and Higher Education Institutions is relatively clearly established among governing bodies and state institutions. At the same time, the competence of special bodies with powers in the field of NIS is enshrined only in their provisions (Ministry of Economic Development, Trade and Agriculture of Ukraine;[31] Ministry of Education and Science of Ukraine; [32] Ministry of Digital Transformation of Ukraine [23]).

\section{Discussion the other scientists and papers}

Thus, most views on the essence of NIS can be divided into the following groups: structural approach (A. Kayal, W. Maloney, S. Feinson, H. P. Klimova and others); subsystem approach (S. Feinson, C. Edquist, L. I Fedulova, E. Viotti); functional and structural (B-A Lundvall and others). However, these models do not sufficiently address the role of the lowest level of the administrative system - the united territorial communities as the only one as close as possible to the governmental structure.

In this direction, it is necessary to perform the broadening of the limits of territorial communities' financial capabilities on the principles of accessibility and sufficiency.

Within the reform of local self-governance, it is necessary to broaden the range of services, providing which can be passed on immediately to local authorities, to develop a number of programs on regions' innovation development that have to provide for beneficial investment conditions for this sector and to avoid the loss of existing assets. Such programs should be fixated at the state level, to get maximum development priority, in fact to become the state's course for a set period of time, because their introduction is resource-consuming and demands that resources be spent under strict control.

It is necessary to introduce special funds within local budgets, which be designated exclusively for accumulating funds to be used later on for financing strategic innovations within activities of communal enterprises and private business structures through mechanisms of regional and local innovation development programs. Such funds can be additionally subdivided by the industry branch principle and ensure the financing of innovation projects in different branches of industry.

To ensure the efficient formation and filling in of such funds, local authorities can involve investors within publicprivate partnerships. Not only are local authorities interested in innovations implementation at a certain territory, but also big business, for which the local innovation potential is one of key factors of further strategic development and maintaining market position, as well as a source of quality human capital.

The basic normative act on this issue is the Law of Ukraine "On State-Private Partnership". According to part 1 Art. 1 of this law, state-private partnership (SPP) is cooperation between the state of Ukraine, Autonomous Republic of Crimea, territorial communities represented by corresponding state bodies and local governing bodies (state partners) and juridical persons, except public and communal enterprises, or physical persons entrepreneurs (private partners), which is accomplished on the basis of an agreement in the order established by this Law and other legislative acts. The aim of such a partnership is raising technical-and-economic rates of utilizing a public partner's property (that of the state, Autonomous Republic of Crimea (ARC), and / or local communities) on the basis of its transfer to a private partner for the long term and with bestowing financialinvestment and social obligations on the private partner. As O. M. Vinnyk notes, for the efficient use of private business' resources, assisting in implementing investment-innovative projects is necessary. [33].

Nevertheless, the Law of Ukraine "On State-Private Partnerships" is unable to solve the problem issues of publicprivate partnership on the territorial communities' level, in particular due to: a) the absence of consolidated methodological approaches to regulating peculiarities of conducting public-private partnerships (methodologies and methods of undertaking an efficiency analysis of such partnerships, of conducting a selection of a private partner, etc.); b) the sequence of multilateral projects' implementation remains unregulated in which, apart from a private partner and a territorial community the state, or the ARC, or other territorial communities, etc. act as another partner. Unfortunately, as of today, not a single SPP project as meant by this Law has ever been completed in Ukraine.

In our opinion, in the present condition, an integral part of the interaction of local authorities with business, apart from public-private partnerships, is the creation of clusters to harness the potential of individual regions. It is necessary to agree with researchers that the basic directions of the definition of a cluster are shown in the development of separate forms of economic activity, participation of separate scientific institutions, formation of separate production chains and networks around big companies. These directions form the most effective eco-innovative systems. [34] 
Uncertainty and impact of research results on science, economy, environment and society.

As a result of this study, no links between NIS elements were found in the regulatory acts of Ukraine. Also, most private sector NIS participants are not identified as entities and their legal forms. The elimination of these shortcomings will enable the NIS to function effectively and promote entrepreneurship in Ukraine.

Institutional transformations should focus primarily on the development of high-tech industries in the industries through:

- unification of highly specialized scientific and design organizations that carry out research and development in the interests of mainly one customer into a single scientific and industrial structure

- establishment of centers of science and high technology on the basis of large scientific institutions leaders in the relevant fields of science and technology

- restructuring of part of sectoral research and design institutes into engineering firms with advanced financial, economic, marketing and commercial infrastructure

- formation business together with higher educational establishments of innovation-technological centers, innovation-industrial complexes, technological and scientific parks, oriented on production of high-tech products which will attract national and foreign investments and take advantage of national and foreign trade network

- creation of small business infrastructure for servicing high technology implementation programs, as well as the creation of basic regional and interregional innovation technology transfer centers to ensure the communication of small enterprises with large enterprises.

\section{Summary and conclusions}

The following steps in legislative regulation are proposed to eliminate the negative NIS factors identified in this article.

Considering the subjective structure of NIS and its current activity mechanism, it is possible to offer the following definition. The national innovation system is, on the one hand, the total sum of interconnected organizations (structures) involved in the production and commercial implementation of scientific knowledge and technologies within national borders: big, medium and small companies, universities, laboratories, techno-parks and incubators, while on the other hand, the complex of institutions of a legal, financial, and social nature that ensure innovation processes and rely on national habits traditions, cultural, and political peculiarities.

For the harmonious and timely development of the National innovation system, making a complex approach to legislation regulating the relationships in the innovation system and its subsystems is necessary. The adoption of the Innovation Code that exists in many EU countries, and the draft of which was developed and presented by Scientific and Research Institute of Providing Legal Framework for the Innovative Development of National Academy of Law Sciences of Ukraine in 2012 may serve as the foundation for this process. [35] The main goals generated in the draft of this Code was regulating the main and most important relations in the National Innovation System, which enhances its harmonious development.

Some of the main tasks should be noted as guidelines for the formation of a system of regulation of innovative activity:

1. Attaining terminological correspondence of the main terms in the sphere of technologies transfer in Ukraine with the EU legislation considering criteria put forward by the EU to the states that aspire to join it.

2. The introduction of an all-sided innovative activity support that includes: financial, credit, tax mechanism, infrastructure development, broadening cooperation between science institutions and the business sector of the EU countries in accomplishing innovation projects.

3. Creating an efficient all-state mechanism of adopting legislation, including the verification of acting normative-legal acts, draft laws of Ukraine, and other normative-legal acts on the issue of their correspondence to the main approaches established by the EU which are compliant with the "Europe 2020" Strategy.

4. Abolition of any limitations of rights of scientific institutions and higher education establishments to spend finances obtained by them from enterprises, grants from international organizations, which may lead to a disruption of budget institutions' activities on the introduction of innovations, or the refusal of enterprises and foreign organizations to conclude contracts with budget-financed institutions, or the impossibility for scientific institutions and higher education establishments to participate in the EU "Horizon 2020" scientific program. 
For bringing the normative-legal base of innovation activity regulation to comply with the Strategy of Innovative Development of Ukraine with the maximum consideration to the regulations, main goals, and standards for the EU countries determined in the "Europe 2020" Strategy, to the following is necessary:

1. Develop a unified system of legislation determining and approving priority directions of science-technical and innovative activities in Ukraine and their implementation, to imbed these legal mechanisms in a comprehensive law, to develop a renovated State Program of prognosticating science-technological development of Ukraine.

2. Develop and legally instill the mechanism of stimulating investments into scientific research and developments, as well as the education sphere, similar to those applied in the EU (exempting the sums spent on scientific research and development, or on higher education establishments' support, faster depreciation of scientific appliances and experimental equipment of science-research institutions and innovative enterprises, etc., from enterprises' taxation base).

\section{Acknowledgement}

This research was financially supported by the fundamental themes of the research "Legal Support of the Functioning of the National Innovation System in Modern Conditions" (state registration number $0117 \mathrm{U}$ 002507), 2017-2020.

\section{References}

[1] I. V. Borysov, Kompetentsiya orhaniv derzhavnoyi vlady shchodo rehulyuvannya diyal'nosti innovatsiynykh struktur, Syevyerodonets'k (2018) 224.

[2] J. O. Adeoti, Building technological capability in the less developed countries: The role of a national system of innovation. Science and Public Policy, Oxford University Press, 29 (2000) 95-104.

[3] Organization for economic co-operation and development. National innovation systems. http://www.oecd.org/science/inno/2101733.pd

[4] H. P. Klimova, Osoblyvosti modeley natsional'nykh innovatsiynykh system. Innovatsiyna systema ta informatsiyni tekhnolohiyi $v$ suchasniy nautsi: materialy vseukrayins'koyi nauk-prakt. konferentsiyi, Kharkiv, (2017) 71.

[5] A. A. Kayal, National innovation systems a proposed framework for developing countries, Int. J. Entrepreneurship and Innovation Management, 8, 1 (2008), 75,81

[6] W. F. Maloney, Revisiting the National Innovation System in Developing Countries (2017) https://openknowledge.worldbank.org/bitstream/handle/10986/28554/WPS8219.pdf?sequence=1\&isA llowed=y

[7] C. Edquist, Systems of innovation for development. Background paper for Chapter 1 "Competitiveness, Innovation and Learning: Analytical Framework" for the UNIDO World Industrial Development Report WIDR) (2001).

https://www.researchgate.net/publication/237322788_Systems_of_Innovation_for_Development_SID_ Background_Paper_for_Chapter_I_Competitiveness_Innovation_and_Learning_Analytical_Framework_f or_the_UNIDO_World_Industrial_Development_Report_WIDR_2001

[8] S.Feinson, National Innovation Systems Overview and Country Cases. Knowledge Flows and Knowledge Collectives: Understanding the Role of Science and Technology Policies in Development, Center for Science, Policy and Outcomes, Columbia University 1, 1 (2003), 21-22

[9] B-A. Lundvall, National Innovation Systems: Towards a Theory of Innovation and Interactive Learning, Printer, London (1992) 13.

https://books.google.com.ua/books?id=iDXGwacw $\backslash 40 C \& p g=P A 43 \& h l=u k \&$ source=gbs toc $r \& c a d=4 \# v=$ onepage \&q=Organizations $\% 20 \& \mathrm{f}=$ false

[10] Concept of development of national innovation system: Resolution of the Cabinet of Ministers of Ukraine of June 17, 2009 N 680-p. https://zakon.rada.gov.ua/laws/show/680-2009-\%D1\%80

[11] Rekomendatsiyi parlament·s'kykh slukhan' na temu: "Natsional'na innovatsiyna systema: stan ta zakonodavche zabezpechennya rozvytku» (Proekt). Parlament·s'ki slukhannya, 2. Kyyiv (2018) 67.

[12] L. I. Fedulova, Tendentsiyi rozvytku natsional'nykh innovatsiynykh system: uroky dlya Ukrayiny, Svitove hospodarstvo ta mizhnarodni ekonomichni vidnosyny (2015) 94-104.

[13] E.Viotti, National learning systems: A new approach on technical change in late industrializing economies and evidences from the cases of Brazil and South Korea. Science, Technology and Innovation Discussion Paper, 12, Center for International Development, Harvard University (2001). http://citeseerx.ist.psu.edu/viewdoc/download?doi=10.1.1.468.1894\&rep=rep1\&type=pdf 
[14] H.P. Klimova, Rol' doslidnyts'kykh universytetiv u formuvanni natsional'noyi innovatsiynoyi systemy, Suchasni problemy rozvytku prava ta ekonomiky $v$ innovatsiynomu suspil'stvi: materialy internetkonferentsiyi, Kharkiv (2019) 53.

[15] H. P. Klimova, Formuvannya innovatsiynoho klimatu u VNZ, Pravo ta innovatsiyi, 4, Kharkiv (2013), 54-64

[16] I. YU. Matyushenko, S. V. Hlibko, M. S. Pasmor, Praktychni aspekty vyznachennya vysokotekhnolohichnykh haluzey i produktsiyi v Ukrayini, Sotsial'na ekonomika, 55 (2018) 37- 49.

[17] O. V. Cherkasov, Osoblyvosti pravovoho rehulyuvannya natsional'noyi innovatsiynoyi systemy v Ukrayini: problemy ta perspektyvy, Innovatsiyna systema ta informatsiyni tekhnolohiyi v suchasniy nautsi: materialy vseukrayins'koyi nauk-prakt. konferentsiyi, Kharkiv (2017), 107-108.

[18] The Law of Ukraine "On Innovation Activity», date of entry into force: August 7, 2002. https://zakon.rada.gov.ua/laws/show/40-15/ed20121205

[19] Law of Ukraine "On Development and State Support of Small and Medium Business in Ukraine date of entry into force: April 19, 2012. https://zakon.rada.gov.ua/rada/show/en/4618-17/sp:max25

[20] S. M. Prylypko, A. P. Het'man, YU. YE. Atamanova ta in. Pravove rehulyuvannya innovatsiynykh vidnosyn, Yurayt, Kharkiv (2013) 131.

[21] V. Gurova Methodology and key determinants of building an efficient national innovation system of a country. International economic policy, 2, 23 (2015) 138-156.

[22] S. V. Hlibko , I. V. Podrez-Ryapolova, Formuvannya rehional'noyi innovatsiynoyi systemy u suchasnykh umovakh, Suchasni problemy rozvytku prava ta ekonomiky $v$ innovatsiynomu suspil'stvi: materialy internet-konferentsiyi, Kharkiv (2019) 42.

[23] Regulation on the Ministry of Digital Transformation of Ukraine: Approved by the Resolution of the Cabinet of Ministers of Ukraine \# 856 of September 18, 2019. https://www.kmu.gov.ua/npas/pitannyaministerstva-cifrovoyi-t180919

[24] The resolution of the Verkhovna Rada on the Recommendations of the Parliamentary Hearings on the State and Legislative Support of the Development of Science and Scientific and Technical Sphere of the State of February 11, 2015, 182-VIII. https://zakon.rada.gov.ua/laws/show/182-19

[25] Regulation on the Procedure of Creation and Functioning of Technoparks and Innovative Structures of Other Types, Approved by the Resolution of the Cabinet of Ministers of Ukraine of May 22, 1996,549 https://zakon.rada.gov.ua/laws/show/549-96-\%D0\%BF

[26] Law of Ukraine "On Scientific Parks", date of entry into force: January 1, 2010. https://zakon.rada.gov.ua/laws/show/1563-17

[27] Law of Ukraine "On Special Regime of Innovative Activity of Technological Parks", date of Entry into Force: July 16, 1999. https://zakon.rada.gov.ua/laws/show/991-14

[28] Law of Ukraine "On Industrial Parks", date of entry into force: September 4, 2012. https://zakon.rada.gov.ua/laws/show/5018-17

[29] Law of Ukraine "On Higher Education", date of entry into force: September 6, 2014. https://zakon.rada.gov.ua/laws/show/en/1556-18

[30] Law of Ukraine "On the Priority Directions of Innovation Activity in Ukraine", date of entry into force: October 2, 2011. https://zakon.rada.gov.ua/laws/show/3715-17

[31] Regulation on the Ministry of Development of Economy, Trade and Agriculture of Ukraine approved by the Cabinet of Ministers of Ukraine of August 20, 2014 № 459 in the wording of the Cabinet of Ministers resolution of September 11, 2019 № 838. https://ips.ligazakon.net/document/view/mn022154

[32] The Regulation on the Ministry of Education and Science of Ukraine was approved by CMU Resolution No. 630 of 16.10.2014, as amended by CMU Resolution № 838 of September 17, 2019. https://zakon.rada.gov.ua/laws/show/630-2014-\%D0\%BF

[33] O. M. Vinnyk, Instytutsiyna forma derzhavno-pryvatnoho partnerstva: problemy pravovoho rehulyuvannya, Aktual'ni pytannya innovatsiynoho rozvytku, Kharkiv (2011) 6-19.

[34] E. Kochanska, M. Kyzym, V. Khaustova, A. Klimek, I. Adamkiewicz, Determinants for development of cluster initiatives in Poland and Ukraine, Acta innovations, 21 (2016) 26-50.

[35] Proekt Innovatsiynoho kodeksu Ukrayiny, Pravo, Kharkiv (2012) 166 